Investigations

\title{
The Technology of Cultivating Lump Crops with Mist Sprinkling in the Conditions of the Zhambyl Region
}

\author{
Nurlan Nurmahanovich Balgabaev, Pavel Alexanderovich Kalashnikov, \\ Aigul Eltaevna Baizakova and Alexander Afanasyevich Kalashnikov \\ Kazakh Scientific Research Institute of Water Economy LLP, Republic of Kazakhstan, \\ 080003, Taraz City, Koigeldy Strit, 12, Kazakhstan
}

Article history

Received: 07-04-2017

Revised: 05-06-2017

Accepted: 13-06-2017

Corresponding Author: Nurlan Nurmahanovich Balgabaev

Kazakh Scientific Research Institute of Water Economy LLP, Republic of Kazakhstan, 080003, Taraz City, Koigeldy

Strit, 12, Kazakhstan

Email: nn.balgabaev@mail.ru

\begin{abstract}
Increasing water scarcity and increasing rate of livestock development in the Republic of Kazakhstan require using new water-saving irrigation methods. Using new forage crops will make it possible to use irrigation water most productively and to achieve the maximum yield with high soil-feeding capacity, while using the minimum amount of irrigation water. Therefore, the main goal of the research was developing a technology of cultivating new fodder crops with mist sprinkling. To save water with optimal water and nutrient regimes, agro technical operations for cultivating crops such as grain and new (for the southern region of Kazakhstan) sorghum and millet, as well as optimal modes of their irrigation with mist sprinkling have been developed.
\end{abstract}

Keywords: Irrigation, Water-Saving Technologies, Fine Mist Sprinkler Irrigation, Equipment, Development, New Fodder Crops, Research, Implementation

\section{Introduction}

Irrigation agriculture is one of the main factors of ensuring stability of agricultural production and food security worldwide.

Analysis of the irrigation technologies and equipment used worldwide leads to the conclusion that from the point of view of water and energy saving, one of the most promising methods is sprinkling.

Development of irrigation contributes to obtaining guaranteed amounts of production, reducing economic risks associated with crop losses due to unstable weather conditions, creating jobs for the rural population, developing localities and several other factors that ensure growth of living standards of the population (Krakovets, 1976a; Dzyubenko, 1976; Nukusheva, 2012; Possibilities of introducing intensive varieties of alfalfa into the fodder production system of the North Kazakhstan region; Fine sprinkling of crops; Crop rotation and crops layout).

The most acute water problems of the country are increasing water shortage, pollution of surface and groundwater with the existing methods of irrigation, huge excessive loss of water, problems of interstate water apportioning and the threat of water resources depletion. At present, hydro land reclaiming systems of Kazakhstan are characterized by deterioration of their ecological status and reduced technical level. This has determined deterioration of soil fertility and, accordingly, loss of agricultural irrigated land.

The absence of modern scientific and technical support for irrigated land reclamation hinders competitive production of agricultural products in the volumes sufficient for covering the needs of the domestic market and forming export resources with the aim of obtaining the leading positions in foreign markets and effective development of the water sector and water policy.

Scientific support for the rational use of water resources and development of technologies of agricultural land reclamation aims at further development of competitive agricultural production (Chichasov et al., 1970; Krakovets, 1976b; Nosenko and Gershunov, 1975; Zharkov, 2000; Kostyakov, 1960) in the volumes sufficient for covering the needs of the domestic market and forming export resources with the aim of obtaining the leading positions in foreign markets and effective development of the water sector and water policy of Kazakhstan.

\section{Methods}

The method of research was patent and information search in the technologies of mist irrigation of 
agricultural crops in the world practice. It was performed with the use of available materials from the fund of the Kazakh Scientific Research Institute of Water Economy LLP (LLP "KazSRIWE"), the scientific library of Taraz, specialized periodicals, media and online resources. The development and research of water saving technology of subsoil water irrigation of fruit plantations and onions were performed according to the methods of field experience (Dospekhov, 1985) with the use of the methods of analyzing agrochemical properties of soils (GOST 26205 -91, 26213-91 GOST, GOST 26423-85). The irrigation regime was monitored by the use of water meters and the level of soil moisture with the thermostat-weight method. The technology of cultivating fodder crops with mist irrigations was developed with scientific substantiation of the choice of fodder crops rotation with regard to the choice of varieties of fodder crops and their soil-feeding capacity. All agricultural work required by the zonal technology of cultivating agricultural crops were taken into account. The phenological and biometrical observations were made according to the standard methods.

\section{Results}

For the rational use of water in the conditions of water scarcity, a technology of cultivating fodder crops with mist irrigation has been developed. The technology was developed to be used on the agricultural lands of the Hamburg LLC in the Zhambyl region and further use at the farms of Zhambyl region.

The object of the research is located in the Zhualyn district of the Zhambyl region. The Zhualyn district is located in the South of Zhambyl region. It is one of the main agricultural areas that provide livestock and crop production for the region. The district borders the South Kazakhstan region and the Kyrgyz Republic.

Irrigated lands of the Hamburg LLP farm are located $1,000 \mathrm{~m}$ above sea level within the Chui valley between the spurs of the Tien-Shan, Karatau and the Kirghiz ridge.

Hamburg LLP, established in 1997, is one of the largest agricultural enterprises for growing and processing agricultural products in the Zhambyl region. To increase crop production, improve product quality and environmental safety of agricultural production, the farm uses wide-coverage, lowintensity sprinkling equipment of circular action with a central drive made in the Netherlands, as well as wide coverage front action and combined action machines and drum type irrigation machines.

The climatic conditions of the region belong to the zone of semi-provided bogara. Rainfall is 400-450 mm per year, including $100-140 \mathrm{~mm}$ during the period with the temperature above $10^{\circ} \mathrm{C}$. The average annual temperature is $+6.7^{\circ} \mathrm{C}$. The hottest months are June through August $\left(18-21^{\circ} \mathrm{C}\right)$, the coldest months are December through February $\left(-6\right.$ to $\left.-8.9^{\circ} \mathrm{C}\right)$. The hydrothermic coefficient is about 1.0 and above. The sum of positive temperatures above $10^{\circ} \mathrm{C}$ is equal to $2,700-2,900^{\circ} \mathrm{C}$. By the results of many years of observation, the climatic characteristics of the studied area are shown in Table 1.

The average annual relative humidity is $65 \%$, the average number of days with relative humidity of less than $30 \%$ per year is $100-120$. The average annual amplitude of air temperatures is $30^{\circ}$. The average annual temperature exceeds $+5^{\circ} \mathrm{C}$ in the spring, in late March early April. Ground frost continues until the end of May and is occasionally observed in June. Autumn colds start in October and ground frost starts in September. The frost-free period lasts on the average for 127 days. The rainfall is unevenly distributed by months. One third of the annual precipitation occurs in the spring and in the summer the precipitation is low. The number of days with snow on the average is 100 . The average snow cover height is $25-35 \mathrm{~cm}$. The area is dominated by the South-West and North-East winds. The strongest winds occur in the spring, when the wind speed reaches $15 \mathrm{~m} / \mathrm{s}$ or higher. The greatest number of days with strong winds is observed in the autumn and in the winter (4-7 days).

By its mechanical composition, the soil is loamy, not salty: The content of easily soluble salts is $0.064-$ $0.339 \%$, salt lime is absent. The filtering properties of clay loams in the unsaturated zone have been defined by experimental watering according to the method of Nesterov; the average value of the water permeability is $0.17 \mathrm{~m} /$ day.

Groundwater on the territory of Hamburg LLP to the depth of $5 \mathrm{~m}$ has not been uncovered.

The described soils are mainly not eroded, however, when they are developed for irrigated agriculture, manifestations of irrigation erosion might be observed. In this respect, depending on the slope of the terrain, they are divided into soils without the risk of erosion, soils with low risk of erosion and soils with high risk of erosion. These factors should be considered when choosing the irrigation equipment for the land to be irrigated.

The technology of cultivating fodder crops with the use of mist sprinkling envisages sticking to all agro technical methods of cultivating agricultural crops under the optimum irrigation regime, as prescribed for this method of irrigation. Since irrigation is one of the main types of works in cultivating agricultural crops, the used irrigation regime should be based on the performance characteristics of the irrigation equipment and the deadlines and norms of irrigation should be set for ensuring the optimal values of soil moisture and the depth of moisturizing. 
Table 1. The climatic characteristics of the studied area

\begin{tabular}{|c|c|c|c|c|c|c|c|c|c|c|c|c|c|c|}
\hline \multirow[b]{2}{*}{ Characteristics } & & \multicolumn{13}{|c|}{ Months } \\
\hline & & I & II & III & IV & $\mathrm{V}$ & VI & VII & VIII & IX & $\mathrm{X}$ & $\mathrm{XI}$ & XII & Year \\
\hline \multirow[t]{3}{*}{ Temperature, $\mathrm{t}^{\circ} \mathrm{C}$} & average & -8.9 & -6.9 & 1.0 & 8.8 & 14.5 & 18.6 & 21.2 & 19.4 & 13.3 & 6.4 & -0.8 & -5.8 & 6.7 \\
\hline & abs. maximum & 16 & 21 & 30 & 33 & 40 & 40 & 42 & 39 & 38 & 34 & 25 & 21 & 42 \\
\hline & abs. minimum & -38 & -40 & -30 & -14 & -7 & -2 & 2 & 0 & -8 & -20 & -42 & 43 & -43 \\
\hline \multirow[t]{3}{*}{ Precipitation, $\mathrm{mm}$} & average & 44 & 48 & 57 & 61 & 50 & 25 & 14 & 6 & 11 & 31 & 48 & 52 & 447 \\
\hline & maximum & 148 & 100 & 166 & 148 & 121 & 58 & 58 & 28 & 32 & 125 & 107 & 105 & 805 \\
\hline & minimum & 3.0 & 1.3 & 7.1 & 18.2 & 2.1 & 0.0 & 0.0 & 0.0 & 0.0 & 0.0 & 0.0 & 0.0 & 206 \\
\hline \multirow[t]{3}{*}{ Relative air humidity, $\%$} & average & 80 & 81 & 80 & 69 & 61 & 54 & 45 & 44 & 48 & 61 & 76 & 80 & 65 \\
\hline & $\geq 80 \%$, days & 11.8 & 9.8 & 9.0 & 3.9 & 1.8 & 0.4 & 0.1 & 0.1 & 0.2 & 3.0 & 8.2 & 11.2 & 59.5 \\
\hline & $\leq 30 \%$, days & 0.2 & 0.2 & 2.7 & 7.0 & 11.4 & 16.4 & 24.5 & 24.2 & 22.3 & 14.8 & 3.9 & 0.7 & 128.3 \\
\hline Absolute humidity, $\mathrm{Mb}$ & 3.2 & 3.7 & 5.3 & 7.5 & 9.5 & 10.8 & 10.5 & 9.1 & 6.6 & 5.6 & 4.4 & 3.5 & 6.6 & \\
\hline \multirow[t]{4}{*}{ Number of days with } & fog & 8 & 8 & 8 & 2 & 0.7 & 0.1 & 0.1 & 0.1 & 0.3 & 2 & 7 & 8 & 44 \\
\hline & thunderstorms & & & 0.6 & 2 & 5 & 6 & 3 & 1 & 0.7 & 0.07 & 0.07 & & 18 \\
\hline & dust storm & & & 0.1 & 0.1 & 0.6 & 0.7 & 1.5 & 1.9 & 2.1 & 2.3 & 0.3 & & 9.6 \\
\hline & wind $>15 \mathrm{~m} / \mathrm{s}$ & 2.1 & 2.8 & 4.0 & 2.4 & 2.8 & 1.5 & 1.1 & 1.4 & 1.5 & 2.3 & 2.2 & 3.3 & 27 \\
\hline
\end{tabular}

The average snow cover height, $\mathrm{cm}$

$\begin{array}{llllllll}X & X I & X I I & I & \text { II } & \text { III } & \text { IV } & \text { Maximum over the winter Stock of water, mm }\end{array}$

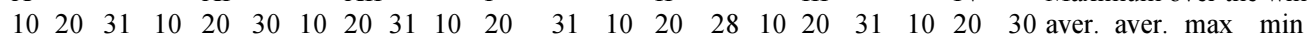

$$
\begin{array}{llllllllllllllllll}
4 & 4 & 6 & 10 & 11 & 12 & 13 & 13 & 13 & 15 & 11 & 11 & 31 & 60 & 10 & 60 & 118 & 30
\end{array}
$$

Dates of start and end of periods with the temperature of, days
Over $0^{\circ} \mathrm{C}$
12.III
Over $5^{\circ} \mathrm{C}$
30.III
Over $10^{\circ} \mathrm{C}$
\begin{tabular}{lrrr} 
& & & 242 \\
20.IV & 205 & & 22.X \\
& & 161 & \multicolumn{2}{c}{ 29.IX } \\
& 9.V & 127 & 14.IX
\end{tabular}
Without frost

10.XI

ance and freezing capacity

Number of days per

year with snow cover

Snow cover

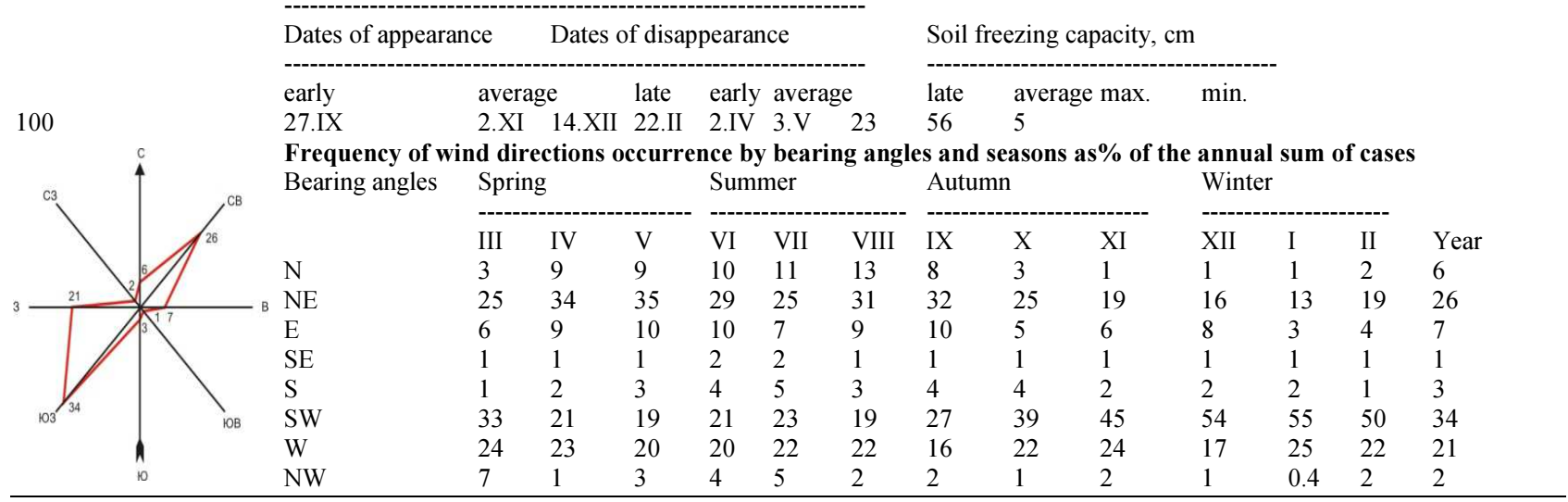

Crop varieties for fodder crop rotation (TCR, 2012; FCR, 2013; Kwan et al., 1989; Agricultural Cultivation of Red Beet; BIP, 2014) have been selected with regard to their soil-feeding capacity for increasing productivity of irrigated lands with the use of mist sprinkling on the territory of Hamburg LLP in the Zhualy district of the Zhambyl region.

For the Northern part of the land of LLC Hamburg, with regard to the mechanical composition of the soils (light loams with pebbles below the $0-60 \mathrm{~cm}$ horizon), the water holding capacity of soils and the shallower depth of the plow layer, the following crop rotation has been recommended (variant 1):

Field 1: Perennial herbs

Field 2: Perennial herbs
Field 3: Perennial herbs

Field 4: Grain maize

Field 5: Maize for silage along with amaranth, sorghum and sunflower + winter crops: Blend (rapeseed, rye, overwintering peas)

Field 6: Winter crops mixture+barley for grain and milled fodder

Field 7: Millet or sorghum for hay and green fodder

For the Southern part of the land of LLC Hamburg, with regard to the mechanical composition of the soils (medium and heavy loams), the water holding capacity of soils and the deeper depth of the plow layer, the following crop rotation has been recommended (variant 2):

Field 1: Herbs 


\section{Field 2: Herbs}

Field 3: Herbs + winter wheat

Field 4: Winter wheat + maize mixture for silage

Field 5: Fodder beet

Field 6: Spring a mixture of oats (Vica), canola + spring barley on for grain and milled fodder

Field 7: Sorghum or millet for hay and green fodder

The technology of cultivating fodder crops with the use of mist sprinkling was developed during formation of the crop rotation (Kalashnikov et al., 2012; 2013; Vaneyan and Menshikh, 2010; CKISP, 2014) on the lands of LLC Hamburg in the Zhualy district of the Zhambyl region in order to determine the possibility of using grain for silage, millet and sorghum for increasing productivity of irrigated lands. Crops for fodder crop rotation have been selected with regard to their soilfeeding capacity. Corn for silage is represented by such varieties as Hybrid VS 678 and Hybrid Donana. Millet varieties are 19586 (late-maturing) and African HHBC Tall, HHBVC Tall, HHVBC Tall and XAIAA. Sorghum varieties are sweet ICSR 93049 (India), grain Boyjugara, sweet Uzbekistan 18, grain Sereta 90 and sweet Stavropol 36.
For irrigating forage crops, modern mist irrigation equipment was used (RSGC, 1962; Aleksandrov et al., 1975), represented by circular TL sprinkling machines on the area of 275 hectares and by 2 drum machines on the total area of 50 hectares. Mist sprinkling irrigation ensures moisturization of the soil, the air above the soil and the above-ground parts of plants under the action of capillary forces. Such irrigation does not cause deterioration of irrigated soils structure. During irrigation, intensity of sprinkling should correspond to the infiltration capacity of the soil. Evaporation of the smallest drops during fall and of the thin film of water created on the surface of plants and soil results in higher relative humidity and lower temperature of air, soil and plants.

Irrigation machines layout and forage crops on the lands with mist irrigation are shown in Fig. 1. The field experiment has been laid out in accordance with the requirements of existing methods (Dospekhov, 1985).

Maize of varieties Hybrid VS 678 and Hybrid Donana was sown on the area of 105 hectares.

Before sorghum and millet were sown, 2 irrigation cycles had been made with a T-L circular sprinkling machine at the rate of $167 \mathrm{~m}^{3} /$ ha for creating reserve of moisture in the soil (Fig. 2).

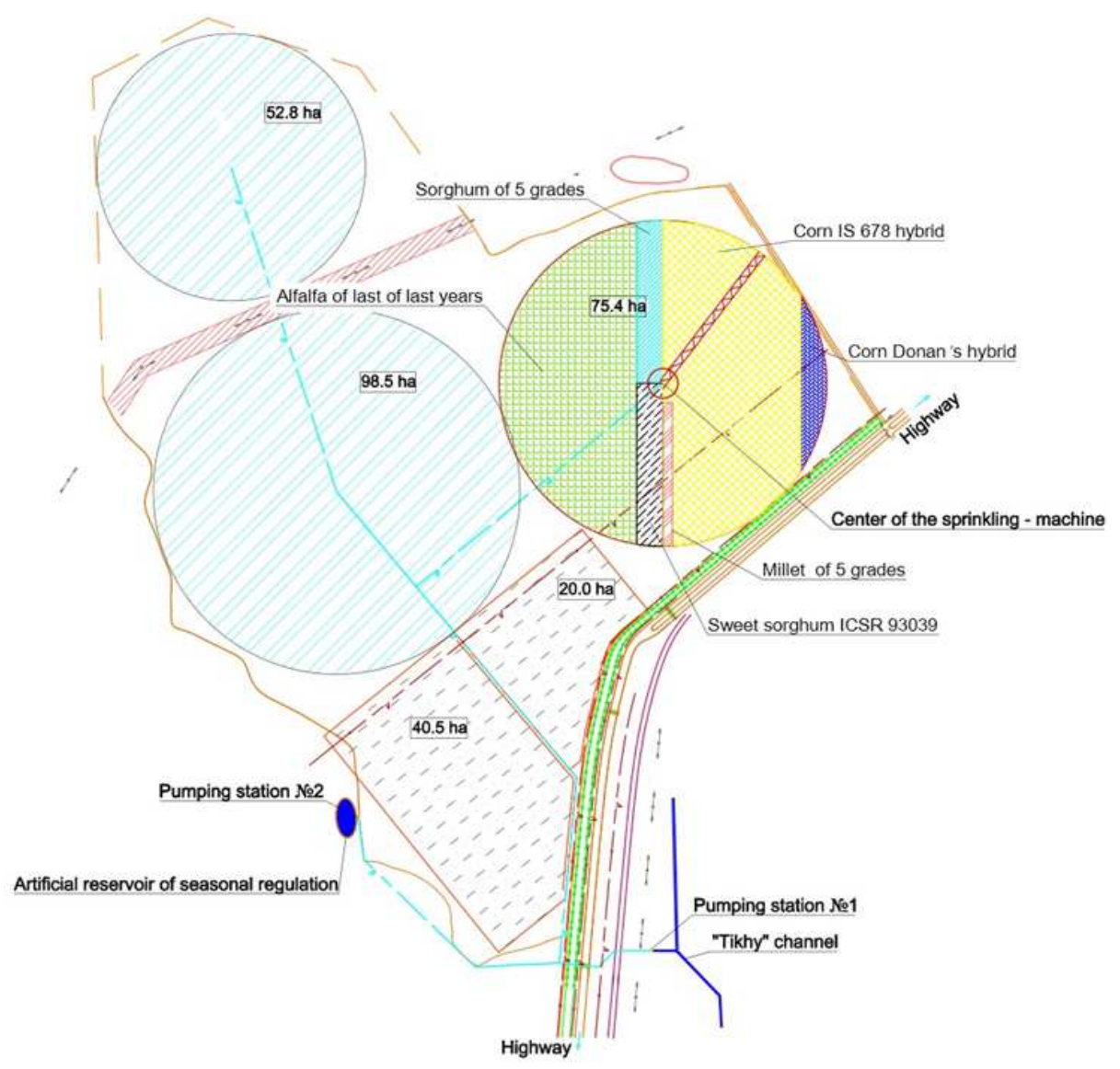

Fig. 1. Layout of sprinkling machines and forage crops 


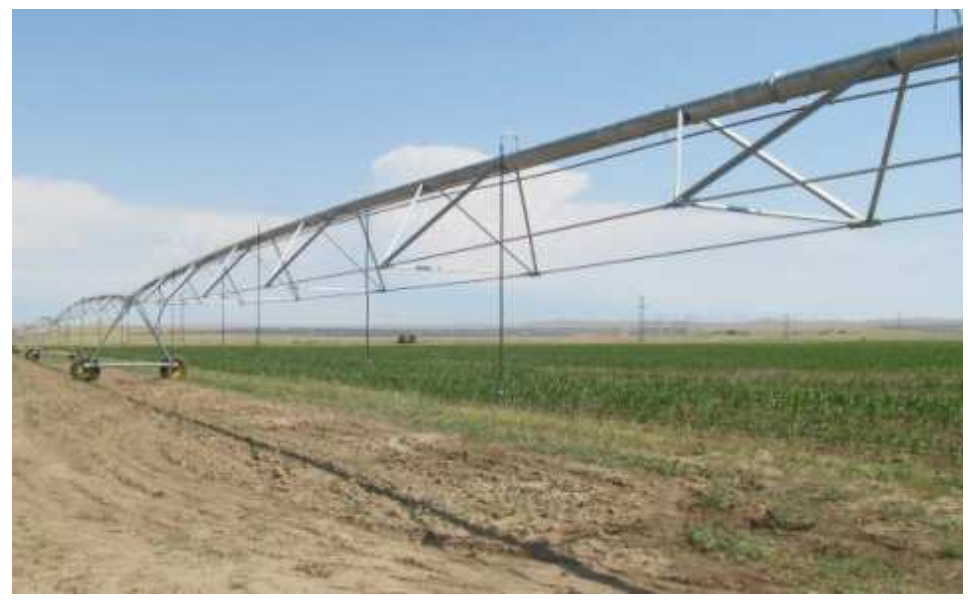

Fig. 2. Irrigation with a T-L circular sprinkling machine

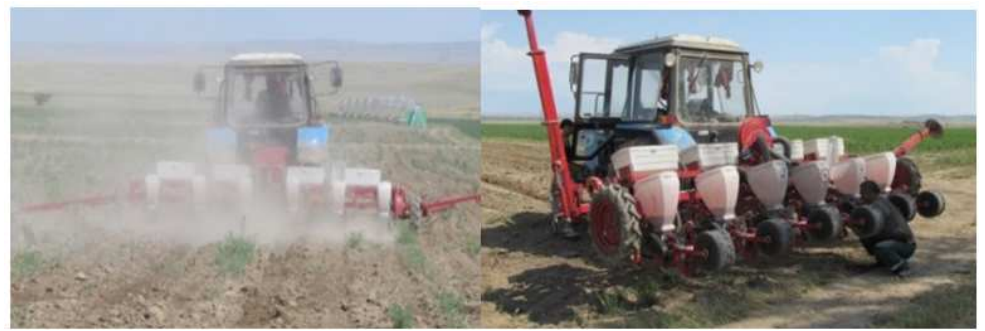

Fig. 3. Sowing seeds of forage and sweet sorghum and millet

Table 2. Agrotechbical operations in crop production

\begin{tabular}{|c|c|c|c|c|c|c|}
\hline \multirow[b]{3}{*}{$\begin{array}{l}\text { Technological } \\
\text { Operations }\end{array}$} & \multicolumn{6}{|l|}{ Crop } \\
\hline & \multicolumn{2}{|l|}{ Maize } & \multicolumn{2}{|l|}{ Sorghum } & \multicolumn{2}{|l|}{ Millet } \\
\hline & Deadlines & $\begin{array}{l}\text { Quality } \\
\text { parameters }\end{array}$ & Deadlines & $\begin{array}{l}\text { Quality } \\
\text { parameters }\end{array}$ & Deadlines & $\begin{array}{l}\text { Quality } \\
\text { parameters }\end{array}$ \\
\hline $\begin{array}{l}\text { Shallow } \\
\text { plowing }\end{array}$ & $\begin{array}{l}\text { d decade of } \\
\text { September to } 1 \mathrm{st} \\
\text { decade of October }\end{array}$ & $\begin{array}{l}\text { Immediately after } \\
\text { harvesting the } \\
\text { preceding crop }\end{array}$ & $\begin{array}{l}\text { d decade of } \\
\text { September to 1st } \\
\text { decade of October }\end{array}$ & $\begin{array}{l}\text { Immediately after } \\
\text { harvesting the } \\
\text { preceding crop }\end{array}$ & $\begin{array}{l}\text { d decade of } \\
\text { September to } 1 \mathrm{st} \\
\text { decade of October }\end{array}$ & $\begin{array}{l}\text { Immediately after } \\
\text { harvesting the } \\
\text { preceding crop }\end{array}$ \\
\hline $\begin{array}{l}\text { Introduction } \\
\text { of mineral } \\
\text { fertilizers }\end{array}$ & $\begin{array}{l}\text { September to } \\
\text { October }\end{array}$ & $\begin{array}{l}3 \mathrm{~kg} / \mathrm{ha} \text { of ammonium } \\
\text { sulfate } 3 \mathrm{~kg} / \mathrm{ha} \text { of } \\
\text { superphosphate }\end{array}$ & $\begin{array}{l}\text { September to } \\
\text { October }\end{array}$ & $\begin{array}{l}3 \mathrm{~kg} / \mathrm{ha} \text { of ammonium } \\
\text { sulfate } 3 \mathrm{~kg} / \mathrm{ha} \text { of } \\
\text { superphosphate }\end{array}$ & & $\begin{array}{l}120 \mathrm{~kg} \text { of } \\
\text { ammophos }\end{array}$ \\
\hline $\begin{array}{l}\text { Boardless } \\
\text { plowing }\end{array}$ & $\begin{array}{l}\text { September to } \\
\text { October }\end{array}$ & $\begin{array}{l}\text { To the depth of } \\
30+35 \mathrm{~cm}\end{array}$ & $\begin{array}{l}\text { September to } \\
\text { October }\end{array}$ & $\begin{array}{l}\text { To the depth of } \\
27-30 \mathrm{~cm}\end{array}$ & $\begin{array}{l}\text { September to } \\
\text { October }\end{array}$ & $\begin{array}{l}\text { To the depth } \\
\text { of } 25-27 \mathrm{~cm}\end{array}$ \\
\hline Harrowingm & $\begin{array}{l}\text { March to } \\
\text { April }\end{array}$ & $\begin{array}{l}\text { When the state of } \\
\text { soil permits and every } \\
\text { time after the rain }\end{array}$ & March to April & $\begin{array}{l}\text { When the state of } \\
\text { soil permits and every } \\
\text { time after the rain }\end{array}$ & March to April & $\begin{array}{l}\text { When the state of } \\
\text { soil permits and every } \\
\text { time after the rain }\end{array}$ \\
\hline $\begin{array}{l}\text { Pre-sowing } \\
\text { Cultivation }\end{array}$ & $\begin{array}{l}3 \mathrm{~d} \text { decade of } \\
\text { April }\end{array}$ & $\begin{array}{l}\text { To the depth of } \\
7-8 \mathrm{~cm}\end{array}$ & $3 \mathrm{~d}$ decade of April & $\begin{array}{l}\text { To the depth of } \\
5-7 \mathrm{~cm}\end{array}$ & $\begin{array}{l}3 \mathrm{~d} \text { decade of } \\
\text { April }\end{array}$ & $\begin{array}{l}\text { To the depth of } \\
4-5 \mathrm{~cm}\end{array}$ \\
\hline $\begin{array}{l}\text { Sowing with } \\
\text { Introduction of } \\
\text { Fertilizers at the } \\
\text { rate of } 60-80 \mathrm{~kg} / \mathrm{ha}\end{array}$ & $\begin{array}{l}\text { 3d decade of } \\
\text { April to } 1 \text { st } \\
\text { decade of May }\end{array}$ & $\begin{array}{l}70 \text { thousand } \\
\text { seeds per } 1 \text { ha }\end{array}$ & $\begin{array}{l}3 \mathrm{~d} \text { decade of April } \\
\text { to } 1 \text { st decade } \\
\text { of May }\end{array}$ & $\begin{array}{l}180 \text { thousand seeds } \\
\text { per } 1 \text { ha }\end{array}$ & $\begin{array}{l}\text { 3d decade of } \\
\text { April to } 1 \mathrm{st} \\
\text { decade of May }\end{array}$ & $4-6 \mathrm{~kg}$ per $1 \mathrm{ha}$ \\
\hline $\begin{array}{l}\text { First } \\
\text { Cultivation }\end{array}$ & $\begin{array}{l}\text { The phase of } \\
4-5 \text { leaves }\end{array}$ & $\begin{array}{l}\text { To the depth of } \\
7-8 \mathrm{~cm}\end{array}$ & $\begin{array}{l}\text { The phase of } \\
4-5 \text { leaves }\end{array}$ & $\begin{array}{l}\text { To the depth of } \\
7-8 \mathrm{~cm}\end{array}$ & $\begin{array}{l}\text { The phase of } \\
3-4 \text { leaves }\end{array}$ & $\begin{array}{l}\text { To the depth of } \\
5-7 \mathrm{~cm}\end{array}$ \\
\hline Weed control & May to June & $\begin{array}{l}\text { In the phase of } 3-4 \\
\text { leaves for weeds }\end{array}$ & May to June & $\begin{array}{l}\text { In the phase of } 3-4 \\
\text { leaves for weeds }\end{array}$ & May to June & $\begin{array}{l}\text { In the phase of } 3-4 \\
\text { leaves for weeds }\end{array}$ \\
\hline $\begin{array}{l}\text { Second cultivation } \\
\text { with top-dressing } \\
\text { First wetting }\end{array}$ & $\begin{array}{l}\text { The phase of } \\
7 \text { leaves }\end{array}$ & $\begin{array}{l}1.5 \text { hwt of ammonium } \\
\text { nitrate per } 1 \text { ha } \\
\text { After the top layer } \\
\text { of soil dries to } 7 \\
\mathrm{~cm} \text { deep }\end{array}$ & $\begin{array}{l}\text { The phase of } \\
7 \text { leaves }\end{array}$ & $\begin{array}{l}1.5 \text { hwt of ammonium } \\
\text { nitrate per } 1 \text { ha } \\
\text { After the top layer } \\
\text { of soil dries to } 7 \\
\mathrm{~cm} \text { deep }\end{array}$ & $\begin{array}{l}\text { The phase of } \\
5-7 \text { leaves }\end{array}$ & $\begin{array}{l}1.5 \text { hwt of ammonium } \\
\text { nitrate per } 1 \text { ha } \\
\text { After the top layer } \\
\text { of soil dries to } 7 \\
\mathrm{~cm} \text { deep }\end{array}$ \\
\hline & $\begin{array}{l}\text { The phase of } \\
9 \text { leaves }\end{array}$ & $\begin{array}{l}\text { Depth to be at } \\
\text { least } 30 \mathrm{~cm}\end{array}$ & $\begin{array}{l}\text { The phase of } \\
9 \text { leaves }\end{array}$ & $\begin{array}{l}\text { Depth to be at } \\
\text { least } 30 \mathrm{~cm}\end{array}$ & $\begin{array}{l}\text { The phase of } \\
9 \text { leaves }\end{array}$ & $\begin{array}{l}\text { Depth to be at } \\
\text { least } 30 \mathrm{~cm}\end{array}$ \\
\hline Harvesting & & $\begin{array}{l}\text { For silage, cobs of } \\
\text { milky-wax ripeness }\end{array}$ & & $\begin{array}{l}\text { For silage in the } \\
\text { phase of stem elongation } \\
\text { with single cob formation }\end{array}$ & & \\
\hline
\end{tabular}


Seeds of sugar sorghum varieties ICSR 93039 (India) were sown at the sowing rate of $8 \mathrm{~kg} / \mathrm{ha}$. Seeds of sugar and grain varieties of sorghum "Stavropolskoye 36" and "Zereta 90" (Russia), "Uzbekistan 18", "Boyjugara" were sown at the sowing rate of $8-9 \mathrm{~kg} / \mathrm{ha}$. The total planting acreage was 60 hectares. The sown millet was represented by following varieties: 19586, HBBC Tall, HHBVC Tall, HHVBC Tall, XAIAA (Fig. 3). The planting acreage of millet was 160 hectares.

A technology of cultivating maize, sorghum for silage and green fodder, millet for hay and green fodder in the South region with mist sprinkling has been developed for the conditions of the Zhambyl region with regard to the varietal characteristics of crops and to the requirements for water supply (Table 2).

\section{Discussion}

Particularities of growing sorghum in the conditions of the studied region:

- Shallow plowing after the preceding crop is performed by disc plows or harrows to the depth of $7-10 \mathrm{~cm}$

- Ammonium sulfate and phosphate fertilizers are introduced before autumn plowing at the rate of at least $3 \mathrm{~kg} / \mathrm{ha}$ of ammonium sulfate and superphosphate

- Board less plowing is performed to the maximum depth, but not less than $30 \mathrm{~cm}$

- Early spring moisture closure with needle harrow BiG-3, followed by harrowing, is performed with the aim of preserving moisture, smoothing of the soil surface and controlling weeds after each significant rain

- Presowing cultivation is performed to the depth of 5-7 cm with simultaneous harrowing with tooth harrows

- Sorghum seed are sown into the soil warmed up to $10^{\circ} \mathrm{C}$ with simultaneous introduction of mixed fertilizers N16P16K16 at the rate of $60-80 \mathrm{~kg} / \mathrm{ha}$. The seeding rate for silage grains is 180 thousand per hectare

- First cultivation-tillage is performed in the phase of 4-5 leaves

- In the phase of 5-7 leaves, crops are treated with herbicides against weeds

- In the phase of 7-8 leaves, nitrogen fertilizers are

- Introduced at the rate of not less than $1.5 \mathrm{t} / \mathrm{ha}$ with simultaneous treatment of the inter-row spacing.

- Starting with the phase of 1-5 leaves, the moisture content in the top soil is continuously monitored to prevent loss of moisture from the root zone.

Watering with the use of mist sprinkling should start with regard to the depth of sowing, without exceeding it, to ensure normal development of the root system of sorghum plants and to eliminate their penetration into the deeper layers of the soil. Beside carry-over, this will make sorghum root system transfer hardly accessible forms of phosphorus into more accessible forms and pull phosphates up from the $1.5-2 \mathrm{~m}$ soil layer to the $30-50$ $\mathrm{cm}$ soil layer. Considering the ability of sorghum to regrow after harvesting for silage, it can provide extra 35 t of green mass:

- In the phase of 9 leaves, deep tillage of the inter-row spacing is required to ensure more rapid penetration of moisture in the lower soil horizons, which contributes to facilitated penetration of sorghum plants root system into deeper soil layers, thereby increasing their erosion and drought resistance and providing the phyto-ameliorative effect on the soil and decreasing its salinity

- The time of mowing sorghum is the phase of stem elongation with single cob formation. The cutting height of 10-12 cm ensures good regrowing

\section{Particularities of Growing Millet in the} Conditions of the Studied Region

The technology of cultivating millet is similar to that of growing maize for grain, silage and green fodder, or of cultivating sweet sorghum for silage, green fodder and hay:

- Shallow plowing of the field after the previous crop is performed by disk plows or a heavy disc harrow to the depth of 7-10 cm immediately after harvesting the preceding crop (safflower, barley, bast fiber)

- Mineral fertilizers are introduced into winter tillage, which is made without shell board. Regarding fertilizers, it is recommended to introduce 1.5-2.0 $\mathrm{kg} / \mathrm{ha}$ of ammonium sulfate and 1.0-1.5 kg/ha of phosphate fertilizer

- With regard to the characteristics of millet plants root system development, the depth of subsurface tillage should be at least $27-30 \mathrm{~cm}$, since $80 \%$ of the roots penetrate to the depth of $40 \mathrm{~cm}$ and they spread to $115 \mathrm{~cm}$ wide

- $\quad$ For obtaining good harvests of millet, the maximum attention should be paid to retaining moisture during spring field works. This requires tillage with needle harrow BiG-3, which ensures knifing and leveling of the soil and weeds removal

- If fertilizers had not been introduced during main plowing, mixed fertilizers N16P16K16 should be introduced at the rate of $1-1.5 \mathrm{~kg} / \mathrm{ha}$ before sowing. Tillage is to be performed to the depth of $5-6 \mathrm{~cm}$

- Millet is to be sown into the soil warmed up to 10$12^{\circ} \mathrm{C}$. This will be end of April - beginning of May; the sowing rate with irrigation is 4 million seeds/ha

- Preferably, sowing should be accompanied by simultaneous introduction of N16P16K16 at the rate 
of not less than $60 \mathrm{~kg} / \mathrm{ha}$. Sowing should better be performed using the wide row method with the inter-row spacing of $45 \mathrm{~cm}$, or in two $60+15+15 \mathrm{~cm}$ lines; the depth of sowing should be 3 to $8 \mathrm{~cm}$, depending on the type of soil and time of sowing

- In the tillering phase, crops are treated with herbicides

- 1-2 inter-row cultivations are made for tillering the inter-row spacing and for weed control. The first treatment should be made after appearance of rows, the second treatment -in the phase of tillering. During the second treatment, corrective fertilization with microelements should be performed

- If necessary, pest control should be performed, with regard to the harmfulness threshold

- The time of harvesting is determined by the purpose of crop cultivation (for grain, for green mass, for hay)

Wetting of agricultural crops with a sprinkling machine in the area of fodder crops started based on the condition of maintaining soil moisture at the optimum level and was performed based on the prevailing climatic conditions throughout the vegetative period of plant development with reference to the main phases of plant development. Soil moisture in the active soil layer was taken as $70-85 \%$ of the nominal value.

In order to improve the physiological performance of plants and reduce the negative influence of high air temperatures in the summer (over $30^{\circ} \mathrm{C}$ ) on their growth and development, irrigation was performed in small dosages once in 1-2 days. Observations of soil moisture in the areas for growing fodder crops showed that during the vegetation periods of plants, it was within the specified level. In the $0-30 \mathrm{~cm}$ layer, soil moisture was $74-88 \%$ of the nominal value, in the $0-50 \mathrm{~cm}$ layer -within the range between 70 and $80 \%$ of the nominal value (Fig. 4).

On the plots for growing fodder crops, growth and development of plants was monitored (Fig. 5a-c), samples of the plants were taken (Fig. 6a-b) and plant were treated with herbicide and nitrogen fertilizers.

An increased soil humidity was observed in the plots adjacent to the track of the irrigation machine (up to $94 \%$ of the nominal value), which seems to be associated with redistribution of surface moisture during irrigation of the higher areas of these plots to the lower areas with the wheel track. The irrigation norms and time of irrigation were, if necessary, adjusted based on the moisture characteristics of the soil and the requirements to it, with regard to the phases of plant development.

The results of observing fodder crops growth and development phases and the elements of agricultural operations at Hamburg LLP in the Zhualy area of the Zhambyl region are shown in Table 3.

In the plots for growing maize, silage biomass of silage maize per plant (cobs up to 1,417 g.) and the number of cobs (1-2) were determined. The weight of cobs ranged from 290 to 400 grams (Fig. 7). The number of grains in maize cobs in the milky-wax phase was counted (500-860 grains). The number of plants per $1 \mathrm{~m}^{2}$ experimental plot was counted by the fodder crops.

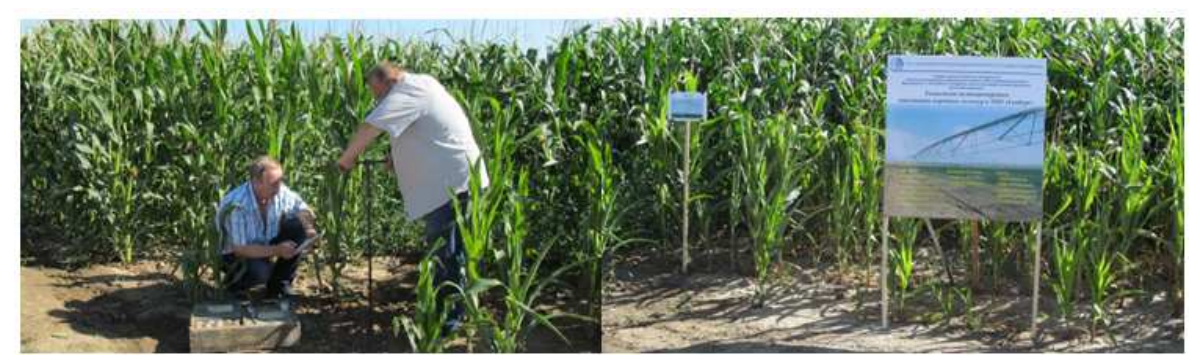

Fig. 4. Observation of soil moisture

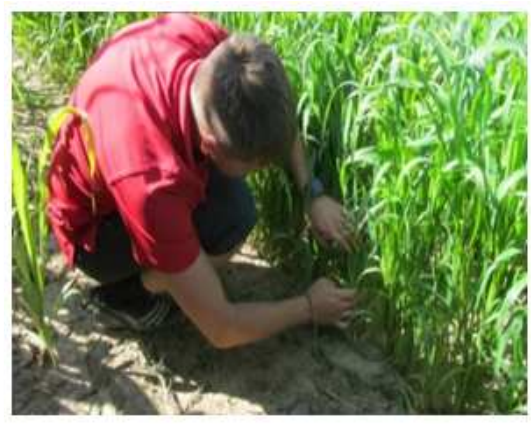

(a)

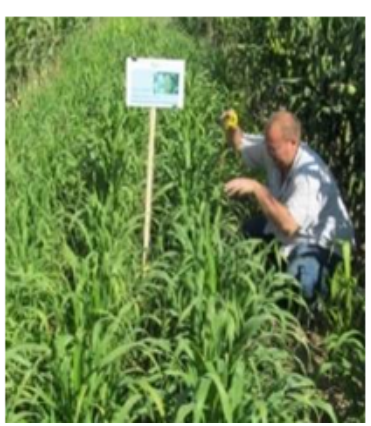

(b)

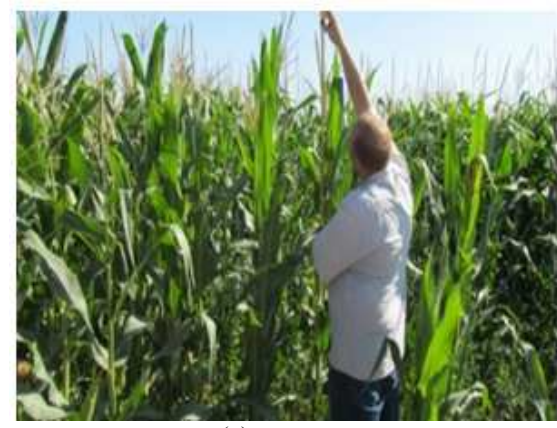

(c)

Fig. 5. (a) Defining millet density (b) Defining height of millet (c) Defining height of silage maize monitoring plants growth and development 


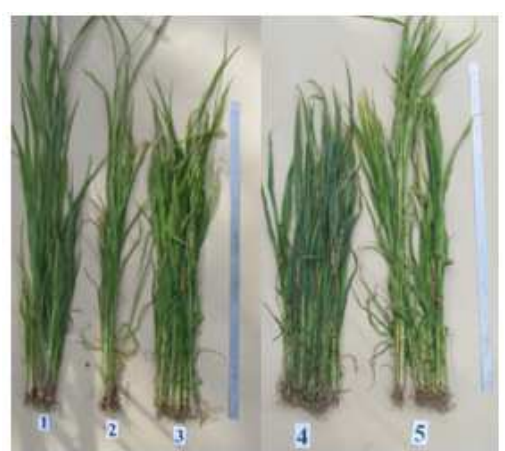

(a)

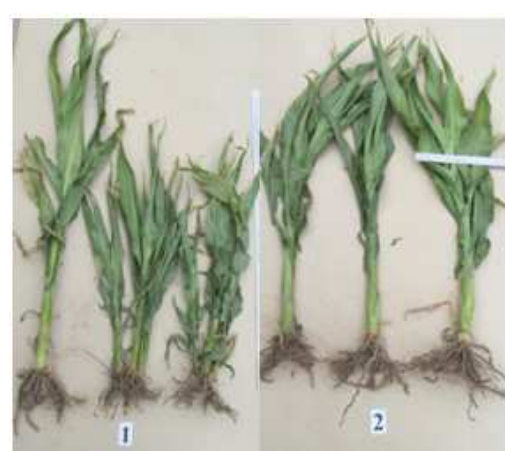

(b)

Fig. 6. Taking samples of plants (a) sampling millet for weighing (b) sampling sorghum for weighing

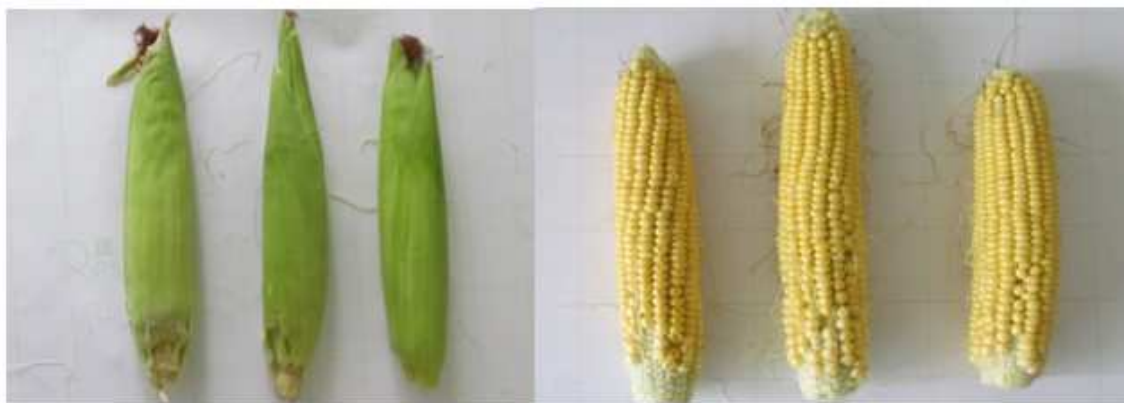

Fig. 7. Cobs of maize for silage

Table 3. Growth and development phases of maize, sorghum, millet and the elements of agricultural methods

\begin{tabular}{|c|c|c|c|c|}
\hline \multirow{2}{*}{$\begin{array}{l}\text { Growth and development phases and } \\
\text { elements of agricultural methods }\end{array}$} & \multicolumn{3}{|l|}{ Crop } & \multirow[b]{2}{*}{ Note } \\
\hline & Maize date & Sorghum & Millet & \\
\hline Sowing & 14.05 .0 & 24.05 .0 & 29.05 .0 & \\
\hline Shoots & 21.05 .0 & 05.06 .0 & 06.06 .0 & \\
\hline The phase of the $3 \mathrm{~d}$ leave & 15.06 .0 & 25.06 .0 & 23.06 .0 & Millet tillering \\
\hline The phase of the 5 th leave & 29.06 .0 & 10.07 .0 & 31.06 .0 & \\
\hline The phase of the 7 th leave & 12.07 .0 & 23.07 .0 & 07.07 .0 & \\
\hline The phase of the 9th leave & 23.07 .0 & 05.08 .0 & 14.07 .0 & \\
\hline The phase of active stem growth & 23.07.-05.08.0 & 10.08 .0 & 10.08 .0 & \\
\hline Phase of head shooting & 31.07 .0 & 27.08 .0 & 06.09 .0 & \\
\hline Phase of graincob formation & 07.08 .0 & & & \\
\hline The phase of milky ripeness & 14.08 .0 & & & \\
\hline The phase of milky-wax ripeness & 26.08 .0 & & & \\
\hline Cultivation & 30.06 .0 & & & \\
\hline Treatment with herbicides & 15.06 .0 & & & Dezormon herbicide \\
\hline 2nd cultivation & 15.07 .0 & & & \\
\hline Top-dressing with nitrogen fertilizers & 15.07 .0 & & & Ammonium nitrate $150 \mathrm{~kg}$ per 1 ha \\
\hline Start of harvesting for the green mass & 01.09 .0 & 03.09 .0 & 08.09 .0 & \\
\hline
\end{tabular}

The biological yield of forage crops was established by the results of measuring the weight of the plants, with regard to their number per 1 ha and after harvesting, the actual yield of forage crops was established (Table 4).

According to the results of the research, the most promising varieties in agriculture are the following: Maize hybrid Donana, millet variety $\mathrm{HH}$ BVC tall and
HH VBC tall, grain sorghum Boyjura and sweet sorghum ICSR 93039, the yield of which was the highest among the cultivated forage crops.

With regard to the climatic characteristics of the region, for Hamburg LLP in the Zhualyn district of the Zhambyl region the bioclimatic method was used for calculating the irrigation norms for maize for silage, sorghum and millet (Table 5-7). 
Nurlan Nurmahanovich Balgabaev et al. / OnLine Journal of Biological Sciences 2017, 17 (2): 110.120 DOI: 10.3844/ojbsci.2017.110.120

Table 4. Biological and actual yield of forage crops at Hamburg LLP

\begin{tabular}{lllllll}
\hline Fodder crop name & $\begin{array}{l}\text { Plant height, } \\
\mathrm{cm}\end{array}$ & $\begin{array}{l}\text { Tillering } \\
\text { coefficient }\end{array}$ & $\begin{array}{l}\text { Average } \\
\text { weight }\end{array}$ & $\begin{array}{l}\text { Number of plants } \\
\text { of 1 plant, g }\end{array}$ & $\begin{array}{l}\text { Biological } \\
\text { yield, } \mathrm{t} / \text { ha }\end{array}$ & $\begin{array}{l}\text { Actual yield, } \\
\text { t/ha }\end{array}$ \\
\hline Hybrid Maize IS 678 & 220 & - & 1,387 & 60,000 & 86.5 & 83.20 \\
Maize hybrid Donana & 214 & - & 1,417 & 60,000 & 92.3 & 85.00 \\
Late-maturing millet 19586 & 160 & 4.5 & 130 & 400,000 & 58.9 & 52.00 \\
African millet & 154 & 3.5 & 150 & 400,000 & 67.3 & 60.00 \\
Millet HH BVC tall & 128 & 3.0 & 175 & 400,000 & 75.9 & 70.00 \\
Millet HH VBC tall & 100 & 2.5 & 200 & 400,000 & 85.6 & 80.00 \\
Millet XAIAA & 139 & 4.0 & 75 & 400,000 & 39.9 & 30.00 \\
Sweet sorghum ICSR 93039 & 137 & 4.0 & 375 & 150,000 & 65.4 & 56.25 \\
Grain sorghum Boyjugurha & 146 & 1.0 & 450 & 150,000 & 72.3 & 67.50 \\
\hline
\end{tabular}

Table 5. Irrigation norms for maize for silage

\begin{tabular}{|c|c|c|c|c|c|c|c|c|c|c|c|c|}
\hline \multirow[t]{2}{*}{ Estimated indicators } & \multicolumn{3}{|l|}{ May } & \multicolumn{3}{|l|}{ June } & \multicolumn{3}{|l|}{ July } & \multicolumn{2}{|c|}{ August } & \multirow{2}{*}{$\begin{array}{l}\text { May- } \\
\text { August }\end{array}$} \\
\hline & II & III & $\mathrm{I}$ & II & III & $\mathrm{I}$ & II & III & $\mathrm{I}$ & II & III & \\
\hline Air temperature, ${ }^{\circ} \mathrm{C}$ & 14.20 & 15.600 & 17.40 & 18.9 & 20.3 & 20.30 & 22.40 & 20.90 & 20.5 & 19.90 & 18.40 & \\
\hline Relative air humidity, \% & 66.00 & 65.000 & 61.00 & 56.0 & 55.00 & 54.00 & 53.00 & 53.00 & 52.0 & 52.00 & 50.00 & \\
\hline Air moisture deficit & 34.00 & 35.000 & 39.00 & 44.0 & 45.00 & 46.00 & 47.00 & 47.00 & 48.0 & 48.00 & 50.00 & \\
\hline Amount of precipitation, $\mathrm{mm}$ & 17.50 & 12.500 & 10.00 & 8.8 & 6.3 & 5.60 & 4.90 & 3.50 & 2.4 & 2.10 & 1.50 & 75.0 \\
\hline Sum of positive temperatures, ${ }^{\circ} \mathrm{C}$ & 85.20 & 256.800 & 430.80 & 619.8 & 822.8 & 1025.80 & 1249.80 & 1479.70 & 1684.7 & 1883.70 & 1994.10 & 2568.0 \\
\hline Active moisture transfer layer, $\mathrm{m}$ & 0.20 & 0.300 & 0.40 & 0.5 & 0.5 & 0.50 & 0.50 & 0.50 & 0.5 & 0.50 & 0.50 & \\
\hline Layer increment & & 0.100 & 0.10 & & & & & & & & & \\
\hline Productive moisture reserves, $\mathrm{m}^{3} / \mathrm{ha}$ & 106.29 & 159.490 & 212.70 & 212.7 & 212.69 & 212.69 & 212.69 & 212.69 & 212.69 & 212.69 & 212.69 & \\
\hline Accretion due to layer deepening, $\mathrm{m}^{3} / \mathrm{ha}$ & & 53.200 & 53.20 & & & & & & & & & \\
\hline Evaporating capacity $\mathrm{E}, \mathrm{m}^{3} / \mathrm{ha}$ & 184.94 & 525.310 & 939.00 & $1,439.00$ & $1,984.00$ & $2,540.90$ & $03,163.90$ & $3,748.10$ & $4,334.40$ & $4,905.30$ & $5,238.70$ & \\
\hline Microclimatic coefficient Ko & 1.00 & 1.000 & 0.90 & 0.90 & 0.90 & 0.80 & 0.80 & 0.80 & 0.80 & 0.80 & 0.80 & \\
\hline Biological coefficient $\mathrm{Kb}$ & 0.61 & 0.640 & 0.67 & 0.74 & 0.81 & 0.87 & 1.02 & 1.07 & 1.03 & 0.96 & 0.86 & \\
\hline Total water consumption, $\mathrm{m} 3 / \mathrm{ha}$ & 112.81 & 336.200 & 566.20 & 958.50 & $1,446.40$ & $1,768.50$ & $2,581.80$ & $3,208.4$ & $3,571.50$ & $3,767.30$ & $3,604.20$ & \\
\hline $\begin{array}{l}\text { Irrigation norm (deficit of water } \\
\text { consumption) }\end{array}$ & -135.50 & 20.713 & 179.50 & 556.80 & $1,030.70$ & $1,352.80$ & $2,145.10$ & $2,786.7$ & $3,153.90$ & $3,355.60$ & $3,207.50$ & 3,200 \\
\hline
\end{tabular}

Table 6. Irrigation norms for sorghum

\begin{tabular}{|c|c|c|c|c|c|c|c|c|c|c|}
\hline \multirow[b]{2}{*}{ Estimated indicators } & \multicolumn{3}{|c|}{ May June } & \multicolumn{3}{|l|}{ July } & \multicolumn{3}{|c|}{ August } & \multirow{2}{*}{$\begin{array}{l}\text { May- } \\
\text { August }\end{array}$} \\
\hline & III & I & II & III & $\mathrm{I}$ & II & III & I & II & \\
\hline Air temperature, ${ }^{\circ} \mathrm{C}$ & 15.60 & 17.40 & 18.90 & 20.30 & 20.30 & 22.40 & 20.90 & 20.50 & 19.90 & \\
\hline Relative air humidity, \% & 65.00 & 61.00 & 56.00 & 55.00 & 54.00 & 53.00 & 53.00 & 52.00 & 52.00 & 51.0 \\
\hline Air moisture deficit & 35.00 & 39.00 & 44.00 & 45.00 & 46.00 & 47.00 & 47.00 & 48.00 & 48.00 & \\
\hline Amount of precipitation, $\mathrm{mm}$ & 8.50 & 10.00 & 8.80 & 6.30 & 5.60 & 4.90 & 3.50 & 2.40 & 2.10 & 52.0 \\
\hline Sum of positive temperatures, ${ }^{\circ} \mathrm{C}$ & 93.60 & 267.60 & 456.60 & 659.60 & 862.60 & $1,086.60$ & $1,295.60$ & $1,500.60$ & $1,600.10$ & \\
\hline Active moisture transfer layer, $\mathrm{m}$ & 0.20 & 0.20 & 0.30 & 0.30 & 0.40 & 0.40 & 0.40 & 0.40 & 0.40 & \\
\hline Layer increment & & & 0.10 & & 0.10 & & & & & \\
\hline Productive moisture reserves, $\mathrm{m}^{3} / \mathrm{ha}$ & 102.29 & 102.29 & 158.89 & 158.89 & 215.49 & 215.49 & 215.49 & 215.49 & 215.49 & \\
\hline Accretion due to layer deepening, $\mathrm{m}^{3} / \mathrm{ha}$ & & & 56.60 & & 56.60 & & & & & \\
\hline Evaporating capacity $\mathrm{E}, \mathrm{m}^{3} / \mathrm{ha}$ & 204.22 & 617.87 & $1,118.10$ & $1,662.90$ & $2,219.90$ & $2,842.90$ & $3,427.00$ & $4,013.30$ & $4,298.80$ & \\
\hline Microclimatic coefficient Ko & 0.90 & 0.90 & 0.90 & 0.90 & 0.90 & 0.80 & 0.80 & 0.80 & 0.80 & \\
\hline Biological coefficient $\mathrm{Kb}$ & 0.61 & 0.640 & 0.67 & 0.74 & 0.81 & 0.87 & 0.88 & 0.89 & 0.90 & \\
\hline Total water consumption, $\mathrm{m}^{3} / \mathrm{ha}$ & 112.12 & 355.890 & 674.24 & $1,107.50$ & $1,618.30$ & $1,978.60$ & $2,412.60$ & $2,857.50$ & $3,095.10$ & \\
\hline Irrigation norm (deficit of water consumption) & -146.20 & 79.605 & 326.36 & 745.64 & $1,199.80$ & $1,539.10$ & $1,988.20$ & $2,437.00$ & $2,680.6$ & 2,700 \\
\hline
\end{tabular}

Table 7. Irrigation norms for millet

\begin{tabular}{|c|c|c|c|c|c|c|c|c|c|c|}
\hline \multirow[b]{2}{*}{ Estimated indicators } & \multicolumn{2}{|l|}{ May } & \multicolumn{3}{|l|}{ June } & \multicolumn{2}{|l|}{ July } & \multicolumn{2}{|c|}{ August } & \multirow{2}{*}{$\begin{array}{l}\text { May - } \\
\text { August }\end{array}$} \\
\hline & III & $\mathrm{I}$ & II & III & $\mathrm{I}$ & II & III & $\mathrm{I}$ & II & \\
\hline Air temperature, ${ }^{\circ} \mathrm{C}$ & 15.600 & 17.40 & 18.90 & 20.30 & 20.30 & 22.40 & 20.90 & 20.50 & 19.90 & \\
\hline Relative air humidity, $\%$ & 65.000 & 61.00 & 56.00 & 55.00 & 54.00 & 53.00 & 53.00 & 52.00 & 52.00 & 51.0 \\
\hline Air moisture deficit & 35.000 & 39.00 & 44.00 & 45.00 & 46.00 & 47.00 & 47.00 & 48.00 & 48.00 & \\
\hline Amount of precipitation, $\mathrm{mm}$ & 8.500 & 10.00 & 8.80 & 6.30 & 5.60 & 4.90 & 3.50 & 2.40 & 2.10 & 52.0 \\
\hline Sum of positive temperatures, ${ }^{\circ} \mathrm{C}$ & 156.000 & 330.00 & 519.00 & 722.00 & 925.00 & $1,149.00$ & $1,358.00$ & $1,563.00$ & $1,662.50$ & \\
\hline Active moisture transfer layer, $\mathrm{m}$ & 0.200 & 0.20 & 0.30 & 0.40 & 0.40 & 0.40 & 0.40 & 0.40 & 0.40 & \\
\hline Layer increment & & & & 0.10 & 0.10 & & & & & \\
\hline $\begin{array}{l}\text { Productive moisture reserves, } \mathrm{m}^{3} / \mathrm{ha} \\
\text { Accretion due to layer deepening, } \mathrm{m}^{3} / \mathrm{ha}\end{array}$ & 112.860 & 112.86 & $\begin{array}{r}169.46 \\
56.60\end{array}$ & $\begin{array}{r}226.06 \\
56.60\end{array}$ & 226.06 & 226.06 & 226.06 & 226.06 & 226.06 & \\
\hline Evaporating capacity $\mathrm{E}, \mathrm{m}^{3} / \mathrm{ha}$ & 170.180 & 583.83 & $1,084.10$ & $1,628.90$ & $2,185.80$ & $2,808.80$ & $3,393.00$ & $3,979.30$ & $4,264.7$ & \\
\hline Microclimatic coefficient Ko & 0.900 & 0.80 & 0.80 & 0.80 & 0.80 & 0.80 & 0.80 & 0.80 & 0.8 & \\
\hline Biological coefficient $\mathrm{Kb}$ & 0.610 & 0.640 & 0.67 & 0.74 & 0.81 & 0.87 & 0.88 & 0.89 & 0.9 & \\
\hline Total water consumption, $\mathrm{m}^{3} / \mathrm{ha}$ & 93.431 & 298.920 & 581.08 & 964.31 & $1,416.40$ & $1,954.90$ & $2,388.70$ & $2,833.20$ & $3,070.6$ & \\
\hline Irrigation norm (deficit of water consumption) & -175.400 & 12.063 & 222.62 & 535.26 & 987.35 & $1,504.90$ & $1,953.60$ & $2,402.20$ & $2,645.5$ & 2,650 \\
\hline
\end{tabular}




\section{Conclusion}

In fact, the sprinkling machine supplied 2,600 to $3,280 \mathrm{~m}^{3} / \mathrm{ha}$ to the fields, including the duration of the growing season of forage crops. Considering water consumption for the microclimate, the irrigation gross norm ranged from 3,016 to $3,805 \mathrm{~m}^{3} / \mathrm{ha}$.

By the results of assessing the crop yield, crops that ensure the highest productivity, such as corn hybrid Donana, millet HH VBC tall and HH BVC tall and grain sorghum Boyjugurha and sweet sorghum ICSR 93039 can be recommended for forage crop rotation in agriculture and for the southern region of Kazakhstan.

\section{Acknowledgment}

This paper is based on the results of the research in the framework of the budget program 254 "Efficient water management". The authors would like to express their gratitude to employees of the "Technologies and irrigation technique" Department of the Kazakh Research Institute of Water Management Zharkov V.A., Angold E.V., Kvan Y.R., Tskhai M.B. and Koch E.E., Head of LLP "Hamburg",

\section{Author's Contributions}

Nurlan Nurmahanovich Balgabaev: Supervised this project, wrote the manuscript and final approved the manuscript.

Pavel Alexanderovich Kalashnikov: Performed the experiment and analyzed the data and wrote the manuscript.

Aigul Eltaevna Baizakova: Performed the experiment and analyzed the data and wrote the manuscript.

Alexander Afanasyevich Kalashnikov: Designed the research, performed the experiment and analyzed the data and wrote the manuscript.

\section{Ethics}

The authors declare no conflict of interest.

\section{References}

Aleksandrov, A.D., B.K. Rassolov, V.Y. Chichasov and V.V. Gorshkov, 1975. Melkodispersnoe dozhdevanie sel'skohozjajstvennyh kul'tur [Fine sprinkling of agricultural crops]. Progressive methods of irrigation, including machine irrigation. International congress on irrigation and drainage. collection of articles by soviet experts. Central Office for Scientific and Technical Information of the Ministry of Land Reclamation and Water Management of the USSR.

CKISP, 2014. Agrarnye onlajn torgi. Pravil'nyj sevooborot [Crop rotation and cropping pattern. Agricultural online trading proper crop rotation].
Chichasov, V.Y., V.V. Izyumov and V.F. Nosenko, 1970. Tehnika Poliva Sel'skohozjajstvennyh Kul'tur [Methods of Crops Watering]. 1st Edn., Kolos, Moscow, pp: 288.

Dospekhov, B.A., 1985. Metodika Polevogo Opyta [Methods of Field Experience]. 1st Edn., Agropromizdat, Moscow, pp: 351.

Dzyubenko, B.V., 1976. Kapelynoe oroshenie v SShA [Drip irrigation in the USA]. Hydraulic Eng. Meliorat., 6: 97-109.

Kalashnikov, A.A., V.A. Zharkov and M.S. Mirdadaev, 2012. Vodosberegajushhaja tehnologija Vozdelyvanija Luka Pri Kapel'nom Oroshenii (Rekomendacii) [Water-saving Technology of Cultivating Onion using Drip Irrigation (Recommendations)]. 1st Edn., KazNIIVH, Taraz, pp: 44.

Kalashnikov, A.A., V.A. Zharkov and M.S. Mirdadaev, 2013. Vodosberegajushhaja Tehnologija Vozdelyvanija Morkovi Pri Kapel'nom Oroshenii (Rekomendacii) [Water-saving Technology of Cultivating Carrots using Drip Irrigation (Recommendations)]. 1st Edn., KazNIIVH, Taraz, pp: 40.

Krakovets, V.I., 1976a. Sistema kapelynogo orosheniya iz mikroporistyh trubok [A drip irrigation system of microporous pipes]. Hydraulic Eng. Meliorat., 8: 114-116.

Krakovets, V.M., 1976b. Dozhdeval'nye mashiny v SShA [Irrigation machines in the USA]. Hydraulic Eng. Meliorat., 6: 107-110.

FCR, 2013. The union for integrated design and management of rural areas. Fodder Crop Rotations.

Kostyakov, A.N., 1960. Osnovy Melioracii [Basics of Amelioration]. 1st Edn., Selkhozgiz, Moscow, pp: 621.

Kwan, R.A., F.F. Vyshpolsky and A.I. Paramonov, 1989. Orositel'nye Normy Sel'skohozjajstvennyh Kul'tur (Rekomendacii) [Agricultural Crops Irrigation Norms (Recommendations)]. 1st Edn., KazNIIVH, Jambul, pp: 74.

BIP, 2014. Melkodispersnoe uvlazhnenie selyskohozyajstvennyh kulytur [Fine moistening of agricultural crops.] Business Innovations Project.

Nosenko, V.F. and E.V. Gershunov, 1975. Ocenka Primenimosti Polivnoj Tehniki [Assessing Applicability of Irrigation Equipment]. In: Hydraulic Engineer Handbook, Alekseev, V.I. and E.V. Gershunov (Eds.), Alma-Ata, Kainar, pp: 111-118.

Nukusheva, J.A., 2012. Vozmozhnosti introduktsii intensivnyh sortov lyutserny $\mathrm{v}$ sistemu kormoproizvodstva Severo-Kazahstanskoj oblasti. Selyskoe, lesnoe i vodnoe hozyajstvo. [The possibility of introducing intensive alfalfa varieties into fodder production in the north Kazakhstan region. Agriculture Forestry Water Economy]. 
RSGC, 1962. Oroshenie i ispol'zovanie vodnyh resursov [Irrigation and Water Use]. Proceedings of the United Nations Conference on Applying Scientific and Technical Knowledge to the Needs of Less Developed Countries, (UNCA' 62), pp: 20-20.

TCR, 2012. Information-analytical portal for peasant farm enterprises. Types Crop Rotation.

Vaneyan, S.S. and A.M. Menshikh, 2010. Rezhim oroshenija, sposoby i tehnika poliva ovoshhnyh i bahchevyh kul'tur v razlichnyh zonah RF [Irrigation Schedule, Ways and Methods of Irrigating Vegetables and Melon and Gourds in Various Areas of the Russian Federation]. 1st Edn., Guide, Moscow, pp: 82
Zharkov, V.A., 2000. Primenenie impul'snogo dozhdevanija dlja oroshenija sel'skohozjajstvennyh kul'tur v predgornoj zone juga Kazahstana [Using impulse sprinkling for irrigating agricultural crops in the foothill area of Southern Kazakhstan]. Research in the Field of Land Development and Water Resources Collection Scientific Works Kazniivh Taraz. 